\title{
LIFE AND THE RIGHT TO LIFE AS THE BASIC CONSTITUTIONAL RIGHT OF A PERSON
}

\author{
Among the natural rights of the colonists are these: \\ First a right to life, secondly to liberty, and thirdly to property; \\ together with the right to defend them in the best manner they can.
}

Samuel Adams

Sibilla Buletsa, Head of the Department of Civil Law and Procedural law, Uzhhorod National University, Doctor of Juridicial Science, Full Professor https://orcid.org/0000-0001-9216-0033

Scopus ID: https://www.scopus.com/authid/detail.uri?authorId=57201856837

ResearcherID: G-2664-2019 (https://publons.com/researcher/1766597/sibilla-buletsa/) sibilla.buletsa@uzhnu.edu.ua

\section{Summary}

The purpose of this article is to study the concept of life and the constitutional right to life, define their essence, the relationship of these concepts, disclose their features, as well as the experience of the European Court of Human Rights in their protection.

In the context of disclosing the subject of research to achieve the goal of scientific research and to ensure the completeness, objectivity, reliability and persuasiveness of the results, the author used a set of general and special methods that are characteristic of legal science. In particular, the origin and long historical path of development of these human rights were studied with the help of the historical method. The use of the system-structural method formulated the general structure of the study, and dialectical method analyzed the provisions of law and case law on the peculiarities of the right to life. Using a comparative legal method, the legislation of foreign countries was analyzed, which provided an opportunity to use their positive experience in terms of protection of the right to human life.

This article reveals the scientific approaches of researchers to determine the essence of life, the right to life, death, identifying their features and distinguishing between them. The paper analyzes ways to protect the right to life. A great deal of the work is devoted to the analysis of the law enforcement practice of the European Court of Human Rights, both in general and on the feasibility of the existence of certain criteria for restricting the right to life.

Based on the study, it is concluded that life and the right to life are similar concepts. It is argued that restrictions on the right to life due to a pandemic are possible if the disease is confirmed. In all other cases, the state must provide free access to coronavirus testing, in the case of a negative test, the opportunity to freely exercise the right to life. It is noted that a significant number of foreign countries provide for the right to life in the constitutions, but there are countries where the right to happiness or physical well-being is still being developed. It is well known that everyone has the right to happiness, which is different for everyone, so the creation of a mechanism to ensure and respect the right to life rests with the state and the individual.

Key words: life, right to life, person, Constitution, European Court, protection. 


\section{Introduction}

Since 1982, the issue of the human right to life has been considered at the UN under the title «Human Rights and Scientific and Technological Progress». The resolutions adopted on this issue emphasize that the right to life is an inalienable right of all people and that implementation of this right is a necessary condition for the realization of the full range of human rights. The UN General Assembly called on States, relevant UN bodies, specialized agencies, interested intergovernmental and governmental organizations to take measures to ensure that the results of scientific and technological progress are used exclusively in the interests of international peace, for the benefit of mankind, and for universal respect for human rights. This confirms the close relationship between the use of scientific and technical results and the protection of human rights, especially the right to life (Bakhin, 1998, p.34). It has been 24 years and given the current situation with the Covid 19 coronavirus pandemic, the world is increasingly turning to new information technology results, to artificial intelligence, to detect, prevent and treat this disease, ie modern information technology protects the human right to life.

The right to life is a fundamental human right enshrined in many universal and regional international legal instruments and in the constitutions of most countries. The human right to life as a natural right arises from the beginning of life and originates from human nature itself (Fedorova, 2009, p.44). The right to life has always attracted scientists and scholars, who, recognizing it as the absolute value of human civilization, have tried to explore all its aspects as deeply as possible. Thus, such well-known domestic and foreign scientists as M.V. Buromensky, V.I. Yevintov, V.N. Denisov, L.G. Zablotskaya, P.M. Rabinovich, R.E. Stefanchuk, S.V. Shevchuk, Y.V. Baulin, O.V. Onufrienko, O.Y. Svetlov, V.A. Kartashkin, V.V. Kozan, Ja.P. Kuzmenko, O.A. Lukashova and other paid their attention to the right to life. Historically, the first ideological prerequisite for the emergence of ideas about the right to life should be considered humanism, which in the days of mythological and religious perception of the world was the basis for denoting the value, independence and uniqueness of human life. The analysis of the evolution of axiological views on human life allowed us to state that in the context of the religious (Christian) worldview there was an interpretation of human nature as spiritual and corporeal. The interpretation of the spiritual and the corporeal in man as antagonistic spheres caused the elevation of the spiritual essence of man with the complete devaluation of man bodily or vital. The ontological essence of human life was associated with the fall of mankind, and its life on earth was associated with the process of its redemption. In medieval philosophical and legal thought, the right to life was not considered as an independent category, because religious axiology did not leave room for human life as a social or even individual value. The status of man in the medieval world, his relationship with society was based on principles that can be defined as a universal «presumption of guilt» (Kuz' menko, 2015, p.25).

John Locke emphasized the right to life, reminding that life is sacred because man is a creation of God. The main thing is that no one could appropriate the life force of another person. Locke opposes economic slavery. Defending the right to freedom, he also opposes political slavery, that is, against any relationship of personal dependence. An individual is a subject of independent beliefs not only from another person, but also from the state. No one should be a servant of the state, the state cannot interfere in the inner world of man.

For example, the Great Charter of Liberties in the thirteenth century enshrined only guarantees of personal inviolability. During the French Revolution, equality and freedom were proclaimed as fundamental values. Only the Declaration of Independence of the United States, adopted in 1776, enshrines that all people are equal and endowed with inalienable rights, including life. Subsequently, in the Universal Declaration of Human Rights, the right to life is enshrined in the subjective right: «Everyone has the right to life ...». Thus, the right to life was clearly enshrined in the Universal Declaration of Human Rights and Freedoms in Art. 3: «Everyone has the right to life, liberty and security of person».

\section{The right to life in the constitutions of the world}

The Constitution of Ukraine proclaimed human life as the highest social value. Central to the system of rights that ensure the natu- 
ral existence of man is the right to life. In June 1998, the Strategy for Ukraine's Integration into the European Union was defined, which states that Ukraine's national interests need to be established as an influential European state, a full member of the EU. Therefore, it is necessary to explore the place of the right to life among the constitutions of European states.

So, the Romanian Constitution by the art. 22 , regulates the right to life, to physical and mental health of the person, in art.26, align. 2, it provides the right of every person to dispose of its own person, without prejudicing the rights and liberties of others, the public order or the morals, art. 34 of the fundamental law guarantee the right to health care (Varvara, Maftei, Negrut, 2012, p.239).

The Turkish Constitution includes rules on the right to life, and restrictions thereof, similar to Article 2 of the Convention. According to Article 17 of the Constitution: "Every one has the right to life.» "The cases of carrying out of death penalties under court sentences and the act of killing in legitimate-defense, the occurences of death as a result of the use of a weapon permitted by law as a necessary measure in cases of apprehension, or the executing of warrants of arrest, the prevention of escape of lawfully arrested or convicted persons, the quelling of riot or insurrection, the execution of orders of authorized bodies during martial law or state of emergency are outside the provision of paragraph 1 (right to life)" (Reisoğlu, 1998-1999, p.4).

The Constitution of the Slovak Republic, where Article 15 stipulates that everyone has the right to life. A person's life must be protected before birth. No one can be deprived of life. Doctor of Embryology Renata Mikushova claims that from a genetic point of view the development of the embryo is based on the principles of determination, ie it belongs to the human species from conception and in its genetic nucleus is encoded information on the basis of which it will develop. Biology considers human development as a long process of human development from conception to death (Forum, 2004, p.2). Microgenets support the position of the beginning of human life from the moment of conception of the human fetus in the womb (Sudo, 2001, p.135).

Article 13 of the Constitution of Japan (Constitution of Japan, 1945) states that all citizens are respected as individuals. The right of people to life, liberty and the pursuit of happiness requires the highest respect in law and other national affairs if it is not contrary to public welfare, and Article 25 of the Japanese Constitution states that «all citizens have the right to live a healthy and cultural minimum» (para. 1). The National Government of Japan must work to improve and promote social welfare, social security and health in all aspects of life (paragraph 2 ), and guarantee the right of people to live and to live as fundamental human rights. Article 25, paragraph 1 , of the Constitution of Japan is a text that can be sufficiently read as a wording calling for cultural life in accordance with the times, which guarantees the content of the right to survival, and as a constitutional basis for cultural rights based on international development trends (Nakamura, 2017). Interestingly, the concept of life includes the right to assistance for the cost of food and beverages, clothing, utilities and other items that meet the basic needs of everyday life. There is a standard of living assistance as the main daily cost of living and a supplement that meets the special needs of pregnant women and people with disabilities. If necessary, temporary assistance will be provided for additional expenses, such as school admissions and the cost of purchasing refrigerators and microwaves needed for a new life (2020). Article 10 of the Constitution of the Republic of Korea states that all citizens have the dignity and worth of people and have the right to pursue happiness. The state is obliged to affirm and guarantee fundamental human rights (Constitution of the Republic of Korea, 1987).

Thus, most constitutions of the world enshrine the right to life, however, it means well-being, happiness, personal development, social assistance and so on. That is, everything that will allow a person to live in comfort, well-being, security. The human right to life is a fundamental right, the most important value of human civilization, which has been recognized and enshrined in the constitutions of many countries.

\section{The concept of life and the right to life}

The concept of natural rights and the concept of human rights arises from the common 
law, which is the right to life, which follows from the human essence, ie ipso facto common law. Human rights are expressed through the right to life, for example, the right to live in a healthy environment, in a social environment where everyone has the right to move freely, has the right to freedom of speech, the right to form societies. Human demands for an adequate standard of living follow from the essence of life and thus create the basic values of protecting life when it is in danger (Blahož, 1998, p.875). The component of the right to personal inviolability as the right to one's own actions includes the right of a person to independently decide on the integrity of his / her body during life or after death and on contact with the environment (Punda, 2004, p.39).

On the one hand, the right to life requires the state to fight against criminal encroachments, terrorist acts in which people die, and on the other hand, the state establishes possible cases of lawful deprivation of life. At the same time, the right to life as the highest value for any person is subject, in any case, to the primary protection of the state (Fedorova, 2009, p.48).

"The right to life is the first fundamental natural human right, without which all other rights remain meaningless, because the dead do not need any rights,» - said Professor M.I. Matuzov (Matuzov, 1998, p.198). Considering this question, it should be noted that depending on the field of application, the category of «life» has a complex structure and is endowed with diverse meanings. For example, from the point of view of philosophy, «life» is understood as a way of being endowed with the inner activity of beings, or the integrity of the reality of being, understood intuitively. The natural understanding of life encompasses the way systems exist, which involves metabolism, irritability, the ability to self-regulate, reproduce, and adapt to environmental conditions. From the point of view of biology, there is also no single approach to defining the concept of life. There are two main areas. Representatives of the first believe that the main in the interpretation of the essence of life is the substrate (protein or DNA molecules), which is the carrier of the basic properties of living things. Proponents of the other direction are convinced that life should be considered in terms of its basic properties (metabolism, self-reproduction, etc.) (Karako, 1998, p.241). Medicine with the concept of «life» covers one of the highest forms of motion and organization of matter, which is formed on the basis of the progressive development of carbon compounds, organic substances and supramolecular systems formed on their basis (Oparim, 1978, p.253). Human life is the unity of three spheres of human existence: physiological life as the functioning of the human body; social life as a set of social relations into which a person enters; inner life, the inner world of man (Zajceva, 2008, p.11). The concept of "life» notes Kalchenko NV in the broadest sense of the word, includes all social relations that allow a person not only to exist as a biological person, but also to socialize, feeling part of society in the process of life (Kalchenko, 1995, p. 27).

Selikhova O.G. believes that human life begins with fetal development, and from birth we should talk about social life. Being in the mother's womb in the state of the embryo, she (man) is physically independent, because it is not part of the body of its carrier and is capable of self-development, because the life processes that take place in it act as an internal driver of its development. The mother's body is only an ideal environment for the development of the embryo, which provides it with nourishment and protection. With birth there is a second stage of biological existence of the person, and is more exact, a stage of stay of an organism in a social environment (Selikhova, 2002, p.13-14).

Defining the concept of «life», Rubanova N.A. assumes the need to protect life by a positive law from conception to the moment of irreversible brain death (Rubanova, 2006).

J.P. Kuzmenko that "the concepts of" right to life «and" life «are not identical» (Kuzmenko, 2017, p.16). So, V.V. Kozhan notes: "The right to life must be viewed through the prism of the concept of 'life', but not identified. After all, life is a biological category, law is a social category" (Kozhan, 2016, p.127). In this context, as noted, A.M. Kolodiy and A.Yu. Oliynyk defines human life as «his bio-social state of existence in time and space» (Kolodiy \& Oliynyk, 2008, p.169). Thus, the category of «life» is broader and can be considered in many aspects - biological, social, spiritual and religious, etc., while the category of «right to life» is only one of those aspects 
that covers the regulated social relations related to the implementation (order), protection and defense of the right to life.

Many definitions of «life» are also offered to us by religious teachings, the sciences of genetics, psychology, psychiatry, and so on. However, of all the variety of definitions of life, we are mostly interested in what would be suitable for law enforcement, ie the definition of life as a non-property good. In our opinion, scientists are close to the truth, who claim that life is inherently a complex concept and includes two main aspects: the biological existence of man and his social development as an intelligent being in time and space. Therefore, the concept of «life» scientists understand the natural (biological and mental) existence and social functioning of the human body as a whole.

So, L.O. Krasavchikova found that in biological terms, «life» - is the physiological existence of man or animal, and "vital activity" - a set of vital supports that make up the body (Krasavchikova, 1983, p.14). However, despite the importance of this definition, it must be agreed that life is only a non-property good, ie the object of civil relations. In order for this good to become legally significant and protected, it must be legally enshrined as the object of the relevant right to life, which is the content of these legal relations with a certain range of powers of its owner (Stefanchuk, 2004, p.44). The right to life cannot be considered only as a right to biological existence, because cloning, transplantation, genetic experiments are problems that also concern the issue of the right to life, so it is necessary to understand this concept more broadly. N.V. Kalchenko notes that the right to life is a natural, inalienable possibility of protecting the inviolability of life and freedom of disposal, guaranteed by domestic law and legal international acts (Kalchenko, 2004, p.75). A similar position is held by G.B. Romanovsky, who notes that the right to life is a fundamental human right enshrined in both major international human rights instruments and national constitutions (Romanovsky, 2006, p. 79).

O.G. Rogova points out that the human right to life is the freedom of man to directly realize the opportunities he has as a result of his belonging to the species Homo sapience, and to meet the necessary essential biological, social, spiritual, economic and other needs inseparable from man himself. are objectively determined by the achieved level of human development and must be universal (Rogova, 2006, p. 13).

The human right to life is an inalienable right of an individual, which ensures his natural existence and is protected by international and national legal acts (Sloma, 2012, p.78). It belongs to all citizens, regardless of belonging to the citizenship of Ukraine from the moment of birth and regardless of the right and legal capacity.

Under the human right to life is understood the total subjective right, which implies provided for the individual by the rules of objective law measure of possible behavior to use life as a social good in order to maintain their biological existence and self-development of the individual by his own factual and legal actions, including requirements to other subjects of law, except the state, and also the absolute obligation provided by the state and society concerning preservation, protection and maintenance of a worthy life (Kuzmenko, 2014, p.30).

In Ukraine, the right to life is also enshrined in the Central Committee, which placed man at the center of any legal system, defining human life as self-worth. Article 281 of the CCU fixes among the first personal non-property rights the right to life. Such a legal characteristic presupposes, firstly, the realization and real provision of human rights as an individual in the conditions of normal life, and not only in violation of these values. Secondly, in order to give stability to public relations and to fulfill their main purpose, new methods and means of legal influence are needed. These factors determine the relevance and significance of the issues under consideration, and necessitate its comprehensive analysis.

However, having identified a number of higher social benefits, the legislator bypassed the issue of their differentiation. In our opinion, it would still be appropriate to recognize at the legislative level that among all the existing non-material goods available, human life is the fundamental component that is at the top of all social priorities, and human life should occupy a decisive position among other social values. After all, if a person loses his life, all other benefits and corresponding rights that arise in relation to them, lose their meaning. 
Despite the role and place that the legislator assigns to human life, another omission, in our opinion, is that there is no official interpretation of life as a personal intangible asset that would promote a common understanding and application of the rules of law governing or protecting legal relations, related to it.

The Civil Code of Ukraine assumes that the right to life should be considered as a broader, broader category, which necessitates a revision of a number of legal concepts and requires the development of new approaches to legal regulation in this area at the present stage.

Human life is a physical, mental, spiritual and biosocial state of human existence that arises from conception and continues to exist until the biological death of a person recognized by the competent health authorities. However, the right to life arises from birth (Buletsa, 2006, p.35).

It should be noted that, the Human Rights Act 1998 sets out the fundamental rights and freedoms that everyone in the UK is entitled to. It incorporates the rights set out in the European Convention on Human Rights (ECHR) into domestic British law. The Human Rights Act came into force in the UK in October 2000. Everyone's right to life shall be protected by law. This right is one of the most important of the Convention since without the right to life it is impossible to enjoy the other rights. Noone shall be condemned to death penalty or executed. The abolition of death penalty is consecrated by Article 1 of Protocol No. 6.

The right to life is regulated in article 2 from the Convention, according to which „The right to life of any person is protected by law. Death cannot be caused with intention, except the death penalty given by the court of law when the crime in sanctioned with this penalty by law". Analyzing in detail the cases where there is no violation of the right to life, in the line 2 of the same article, the Convention provides that "death is not considered to be caused by the violation of this article in case it results from force proven to be absolutely necessary: a) in order to ensure the protection of any person against illegal violence (self-defence); b) in order to make a legal arrest or to prevent the escape of a person lawfully detained; c) in order to suppress, according to the law, a riot or an insurrection"
(Coman, Maftei \& Negrut,, 2012, p.241). According to this regulation, it results that the right to life is "intangible". By adopting the Protocol 6 of the European Convention of Human Rights, the European Council gave a special attention to death penalty, stating the rule according to which "nobody can be convicted to such a penalty, nor executes", excepting the cases when, at national level is provided the death penalty for exceptional situations (crimes of war or of imminent danger of war). The Protocol 13 of the same convention, signed at 3 May 2002, solves this problem in a radical way by determining the member states of the Europe Council to eliminate the death penalty in any circumstances, eliminating any derogation from this rule. The jurisprudence of the European Court of Human Rights was a fundamental element in the research of the content regarding the right to life, confronting with cases where there was asked to identify the limits of the right to life in cases of euthanasia, and regarding the right to life of the fetus. In the jurisprudence of the Court there are various cases regarding the protection of the right to life including cases regarding euthanasia, the right to life of the fetus, and situations where there was asked for the conviction of the states for breaking the right to life by the lack of investigations in cases of missing or suspect death (Selejan-Guţan \& Rusu, 2006, p. 136).

For example, in Hungary, Slovakia and the Czech Republic, the right to life arises from the moment of conception, provided that the child is born alive, and is also a basic personal inalienable right. In addition, everyone's life is good not only for them. It is one of the highest social values for Ukrainian society, as emphasized in Article 3 of the Constitution of Ukraine, and for the world, as follows from a number of international conventions, and society's attitude to the life of each individual is the best indicator of its cultural and spiritual development.

Thus, in most European countries, the unborn child has the right to life. In Ukraine - just born. This means that an 8-month-old fetus that has all the characteristics of a human, but does not have the right to life.

\section{Protection of the right to life}

Everyone's right to life is defined as an inalienable right and universally recognized by the 
international community. This means that such a right cannot be separated from the holder either voluntarily, compulsorily, permanently or temporarily. An individual cannot be deprived of the right to life. However, this wording in $\mathrm{Ar}$ ticle 281 of the Civil Code of Ukraine does not quite correspond to the provisions of the Constitution of Ukraine, which declares that no one can be arbitrarily deprived of life (Article 27 of the Constitution of Ukraine). At the same time, the state cannot guarantee that all people will live forever, because it depends on the state of health and on the person himself (suicide) (Rabinovich \& Havronyuk, 2004, p.260). It also means that no one can be deprived of life without a proper legal basis. But the death penalty is not the only legal way to restrict the right to life of individuals. Such methods, for example, can also include the necessary defense (Article 1169 of the Civil Code of Ukraine). In this regard, the constitutional provision on the prohibition of arbitrary deprivation of life seems more precise (Stefanchuk, 2003, p.89).

According to Article 2 of the EC (European Convention on Human Rights), deprivation of life is not considered a violation of the right to life, when it is a consequence of the inevitable need to use force: a) to protect anyone from unlawful violence; b) in the event of a lawful arrest or in the prevention of the escape of a person lawfully in custody; c) during acts committed lawfully in order to suppress a riot or insurrection.

The limits of the realization of the human right to life are also established by giving a person the right to protection of his own life from unlawful encroachments through the use of opportunities provided by the institutions of extreme necessity and necessary defense. The Constitution of Ukraine stipulates that no one shall be subjected to torture or to cruel, inhuman or degrading treatment or punishment. To ensure the correct and uniform application of the law in cases of crimes against life and health, a resolution of the Plenum of the Supreme Court of Ukraine was adopted, which provides in detail the conditions for liability for crimes against life and health. This provision is confirmed by the Hungarian directive on the protection of life and health, which emphasizes that encroachment on human life is the most serious crime, ie encroachment on human life is prohibited by law. As already mentioned, the right to life is an inalienable human right, ie neither the state nor society can violate this right, and its protection is the duty of the state. Violation of these rights causes an individual to a state where he can, without sparing his life, challenge society and the state, defending their inalienable rights and freedoms (Danilov, 2002, p.62).

What concerns the US and the UK both already having implemented individual human rights sanctions, the EU is about to enact its own human rights sanctions regime: The European Commission and the EU High Representative for Foreign Affairs, Josep Borrell, have recently presented a proposal for the introduction of EU human rights sanctions. This follows an announcement by the President of the European Commission, Ursula von der Leyen, in her September 2020 State of the Union Address on the Commission's attention to bring forward such EU human rights sanctions framework.

The EU's move towards human rights sanctions comes after the UK adopted a similar sanctions regime this summer and increasing pressure by different stakeholders on the implementation of EU human rights sanctions. The idea for a global human rights sanctions programme originates form the US Magnitsky Act which was adopted in response to the killing of Russian whistleblower Sergei Magnitsky in 2009.

The global regime of EU sanctions for human rights violations - namely the name of the European version of the American «Magnitsky Act», will not be tied to specific names or countries, but will impose sanctions on individuals and institutions involved in serious human rights violations all over the world. It must be adopted unanimously 7.12.2020. Sanctions can be applied to both state and non-state actors, people and organizations. Therefore, the range of individuals and legal entities that will be able to fall under the new restrictive measures is very wide. Sanctions can be applied for human rights violations where they would not be committed in the world. While the draft is not available for the public yet, it is expected to include the imposition of asset freezes and travel bans on individuals / entities responsible for serious human rights violations, including genocide, torture, crimes against humanity, slavery, 
human trafficking, extrajudicial killings, sexual violence. Other than with the current economic / cyber / chemical weapons sanctions, the proposal would provide the European Commission with oversight functions on the implementation of travel bans. The set of sanctions instruments is normal: it is a ban on travel to the European Union and the freezing of financial assets (Sanctions And Human Rights, 2020).

Gabriel Toggenburg said that there are at least three reasons why it is important the EU Charter protects the right to life (Toggenburg, 2020): Firstly, the scope of EU legislation is expanding. Back in 2000 when the Charter was proclaimed, questions of 'life and death' were beyond the EU's scope. This has changed as the European Arrest Warrant or the fight against terrorism show. Or take the example of FRONTEX and the protection of the EU's external border, not to mention the Common Foreign and Security Policy of the EU and possible EU military missions in third countries: all contexts where the EU could run the risk of violating the right to life. Secondly, the right to life goes beyond drastic scenarios. It is present and relevant also in more daily contexts. The right to life might for instance pop up in the context of public health and the question of what sort of claims can be made in advertisements for medicinal products. Or even in the context of environment given that the EU rules on, for instance, air quality can be seen as putting ,in concrete terms the Union's obligations to provide protection following from the fundamental right to life“. Thirdly, the EU has been propagating the abolition of the death penalty vis-à-vis third countries for many years and continues to do so. In fact, the global trend is positive. 142 countries, representing three quarters of the UN member states, have stopped using the death penalty. In 2018, executions were carried out in 20 countries, "representing a historic low of $10 \%$ of the countries of the world". Committing internally to the prohibition of the death penalty increases the EU's legitimacy when fighting the death penalty externally.

This does not provide for the additional right to die to be conferred, unlike the Universal Declaration of Human Rights, the ICCPR or the Bill of Rights Act because it explicitly states the situations that do not contravene the order that "No one shall be deprived of his life intentional- ly”. That the right to life implies a right to choose to not continue living may still be inferred however, as was argued in Pretty v United Kingdom: "...the Article recognises that it is for the individual to choose whether or not to live and so protects the individual's right to self-determination in relation to issues of life and death. Thus a person may refuse lifesaving or life-prolonging medical treatment, and may lawfully choose to commit suicide. The Article acknowledges that right of the individual. While most people want to live, some want to die, and the Article protects both rights. The right to die is not the antithesis of the right to life but the corollary of it, and the State has a positive obligation to protect both."6 This argument was rejected by the European Court of Human Rights, concluding that the right to life is unconcerned with what a person chooses to do with their life: "Article 2 cannot, without a distortion of language, be interpreted as conferring the diametrically opposite right, namely a right to die; nor can it create a right to self-determination in the sense of conferring on an individual the entitlement to choose death rather than life." Arguing that the right to life also grants a right to death may be unfounded, but there is compelling reason to support an additional right to choose whether to live or die. It seems that the right to life is not inconsistent with a right to die, but is not sufficient to protect assisted suicide alone (Holford, 2012, p.25).

The Court has held that no right to die, whether at the hands of a third person or with the assistance of a public authority, can be derived from Article 2 of the Convention. It underlined that the consistent emphasis in all the cases before it has been the obligation of the State to protect life (Pretty v. the United Kingdom, § 39).

In the case of Vo v. France, where the applicant had to undergo a therapeutic abortion as a result of medical negligence, the Court considered it unnecessary to examine whether the abrupt end to the applicant's pregnancy fell within the scope of Article 2, seeing that, even assuming that that provision was applicable, there was no failure on the part of the respondent State to comply with the requirements relating to the preservation of life in the public-health sphere (§ 85; see also for a similar approach Mehmet Şentürk and Bekir Şentürk v. Turkey, § 109) (Guide, 2020, p.17). 
The problem of protection of the right to life in Ukraine remains relevant, and therefore there is a European mechanism for the protection of such a right, which provides an opportunity for a person whose right has been violated to obtain fair satisfaction. In order to obtain justice from the European Court, it is proposed to understand with arguments: whether the fact of violation of the right to life was true, whether the restriction of the right met the three-part test, whether the state took measures to prevent or eliminate the violation and whether there are real grounds, evidence, etc.) to bring the state to justice (Shevchenko, 2018, p.306).

The protection of the right to life occurs under any circumstances, to any person, regardless of race, nationality, religion, sexual orientation in any way, provided that no harm is done to other living beings, regardless of place of residence, status, sanctions for violation the right to life applies under all conditions.

The right to life today is not an inalienable human right, because in the context of Covid 19 pandemic there is a constant restriction and violation of the right to human life, the right to unconfined movement. A person is deprived of the right to personal, physical development due to the lockdown introduced by most of the states. The current situation in the world leads to the conclusion that the violation of the right to life occurs for unexpected reasons, for all people with no-expection in omnipresent places. States are unable to protect people from the coronavirus that is spreading around the world and thus violate human rights to life by restricting a person's ability to move, make new contacts, generate business income, and communicate with each other.

\section{Conclusions}

The constitutions of the world provide for the right to life, happiness, and well-being, and respect for these rights must be instilled in children from an early age. Despite the role and place that the legislator assigns to human life, another omission is that there is no official interpretation of life as a personal intangible asset that would promote a common understanding and application of the rules of law governing or protecting legal relations related to with him.

What states need to do is to develop a clear, adaptive mechanism of actions, in order to pro- tect the citizens without violating their right to life. This mechanism needs to be constantly revised and improved according to the newest scientifically proven data. Also, this can include pre-pandemic preparations of the medical care system on a larger scale, on smaller - access to free testing with quick results on a daily basis.

The protection of the right to life occurs under any circumstances, to any person, regardless of race, nationality, religion, in any way, provided that no harm is done to other living beings, regardless of place of residence, status, ie sanctions for violation the right to life applies under all conditions. The opportunity to freely exercise the right to life needs to remain protected.

\section{Bibliography:}

1. Бахин, С. В. (1998). Всеобщая декларация 1948 года: от каталогов прав человека к унификации правового статуса личности. Правоведение, 4, С.34-35

2. Булеца, С. Б. (2006). Право фізичної особи на життя та здоров'я (порівняльно-правовий аспект). Монографія. Ужгород, Поліграфцентр „Ліра”, 172 с.

3. Данілов, С. О. (2002). Ідея невід'ємних прав людини у Конституції України. Держава і право, 18, С.61-65

4. Зайцева, А. М. (2008). Жизнь человека как объект конституционноправового регулирования (автореф. дис.... канд. юрид. наук: 12.00.02). М., 28 с.

5. Кальченко, Н. В. (2004). Гражданские права человека: современные проблемы теории и практики. Монография. Волгоград, 187 с

6. Кальченко, Н. В. (1995). Право человека и гражданина на жизнь и его гарантии в РФ (дис. ...канд. юрид. наук: 12.00.02). Волгоград, 1995, 193 с.

7. Карако, П. С. (1998). Жизнь. Новейший философский словарь. Сост. А.А. Грицианов. Минск: Изд. В.М. Скакун,

8. Кожан, В. В. (2016). Особисті права та свободи людини: загальнотеоретичне дослідення (дис. ... канд. юрид. наук: 12.00.01). Львів, 229 с.

9. Колодій, А. М., \& Олійник, А. Ю. (2008). Права, свободи та обов'язки людини і громадянина в Україні. Підручник. К., Всеукраїнська асоціація видавців «Правова єдність», 350 с.

10. Красавчикова, Л. О. (1983). Личная жизнь граждан под охраной закона. М.: Юридическая литература, $160 \mathrm{c}$.

11. Кузьменко, Я. П. (2014). Загальна характеристика права людини на життя. Науковий вісник Ужгородського національного університету. Серія Право, 28, Том 1, C.26-30 
12. Кузьменко, Я. П. (2015). Право людини на життя: історико-правові аспекти. Юридичний науковий електронний журнал, 3, C.25. URL: http://www.lsej.org. ua/3_2015/6.pdf

13. Кузьменко, Я. П. (2017). Право на життя як природне право людини: теоретико-правовий аналіз. Науковий вісник Ужгородського національного університету. Серія «Право», 46, Т.1, С. 15-18

14. Матузов, Н. И. (1998). Право на жизнь в свете российских и международных стандартов. Правоведение, 1, С.198 - 203

15. Опарим, А. Й. (1978). Жизнь. Большая медицинская энциклопедия. Гл. ред. акад. Б.В. Петровский. Т.8: Евгеника-Зыбление. М., Изд. «Советская знциклопедия», С.253-258.

16. Про захист прав людини і основоположних свобод. (1950): Конвенція. URL: https://zakon.rada.gov.ua/ laws/show/995_004\#Text

17. Про судову практику в справах про злочини проти життя та здоров'я особи (2003): постанова Пленуму Верховного Суду №2. URL: https://zakon.rada.gov.ua/ laws/show/v0002700-03\#Text

18. Пунда, О. О. (2004). Право на фізичну недоторканність у системі особистих немайнових прав фізичної особи. Вісник Верховного Суду України, 7(47), С.38-40

19. Рабінович, П. М., Хавронюк, М. І. (2004). Права людини і громадянина. Навчальний посібник. К. Атіка, 464 с.

20. Рогова, О. Г. (2006). Право на життя в системі прав людини (автореф. дис.... канд. юрид. наук:12.00.01). Х., 21 с.

21. Романовський, Г. Б. (2006). Право на жизнь: юридическая норма и доктрина. Університетські наукові записки, 2(18), С. 75-79.

22. Рубанова, Н. А. (2006). Право человека на жизнь в законодательстве РФ: понятие, содержание, правовое регулирование. (дис. ... канд. юрид. наук: 12.00.01). Ростов-на-Дону», 24 с.

23. Селихова, О. Г. (2002). Конституционно-правовые проблемы осуществления права индивидов на свободу и личную неприкосновенность. (дис. ... канд. юрид. наук: 12.00.02). Екатеринбург, 23 с.

24. Слома, В. М. (2012). Право на життя як особисте немайнове право фізичної особи. Юридичний вісник, 1(22), C.77-81. URL: http://www.law.nau.edu. ua/images/Nauka/Naukovij_jurnal/2012/statji_ n1_22_2012/Sloma_77.pdf

25. Стефанчук, Р. О. (2004). Право на життя як особисте немайнове право фізичної особи. Юридична Україна, 7, С.44-49.

26. Стефанчук, Р.О. (2003). Цивільно-правові засади закріплення, здійснення та охорони права на життя як особистого немайнового права фізичних осіб.
Методологія приватного права: 36 наук. пращь. К. Юрінком Інтер, 2003, 480 с.

27. Судо, Ж. (2001). Біологічний статус людського ембріона (доповідь для медиків). Родина і биоэтика, 5 , C.131-139

28. Федорова, А. Л. (2009). Право на життя як невід'ємне природне право людини. Актуальні проблеми міжнародних відносин, 83, (Частина II), С.43-49.

29. Цивільний кодекс України (2003): Закон України №435-IV. URL: https://zakon.rada.gov.ua/laws/ show/435-15\#Text

30. Шевченко, Ю. А. (2018). Механізм захисту права на життя у світлі практики європейського суду з прав людини у справах проти України. «Young Scientist», 3 (55), March, C. 301-307

31. 대한민국헌법 [시행 1988. 2. 25.] [헌법 제10호, 1987. 10. 29., 전부개정]. URL: https://www.law.go.kr/lsEflnfoP.do?lsiSeq=61603\#

32. 中村 美帆. 日本国憲法第25条「文化」概念の 研究一文化権 (cultural right) との関連性. (2017). URL: http://www.l.u-tokyo.ac.jp/postgraduate/database/2017/6187.html

33. 日本国憲法. (1945). URL: https://elaws.e-gov.go.jp/ document?lawid=321CONSTITUTION

34. 生活保護制度. URL: https://www.gender.go.jp/policy/ no_violence/e-vaw/law/22.html

35. Aj nenarodené diet́a má právo na život. (2004). Spravodaj občianskeho združenia Fôrum života, 3, S.1-16

36. Blahož, Josef. (1998). Úvaha o podstatě lidských a občanských práv (1998). Právnik, 10-11, C.874-894

37. Coman, V., Maftei J. \& Negrut V. (2012). The Right to Life. Conference: EIRP, 7, p. 239-243.

38. Gabriel, Toggenburg. (2020). The 2nd of all EU-r rights: the right to life and what the Charter has to contribute. URL: https://beta.eurac.edu/en/blogs/eureka/the2nd-of-all-eu-r-rights-the-right-to-life-and-what-thecharter-has-to-contribute

39. Guide on Article 2 of the European Convention on Human Rights. Right to life. (2020). URL: https://www.echr.coe. int/documents/guide_art_8_eng.pdf

40. Safa, Reisoğlu. (1998-1999). Right to life. Perceptions journal of international affairs, III (4). URL: https://dergipark.org.tr/en/download/article-file/817142

41. Sam, Holford. (2012). There is a right to life; is there a right to die? The New Zealand Medical Student Journal, 16 (November), P.25 URL: http://www.nzmsj.com/uploads/3/1/8/4/31845897/16_feature2.pdf

42. Sanctions and Human Rights: towards a European framework to address human rights violations and abuses worldwide. (2020). URL: https://ec.europa.eu/ commission/presscorner/detail/en/ip_20_1939 
43. Selejan-Guţan, B., \& Rusu, H. (2006). Jurisprudenţa CEDO/ ECHR Jurisprudence. Bucharest: Hamangiu, Updated on 31 August 2020, P.17. URL: https://www. echr.coe.int/Documents/Guide_Art_2_ENG.pdf

\section{References:}

1. Bakhin, S. V. (1998). Vseobshchaya deklaratsiya 1948 goda: ot katalogov prav cheloveka k unifikatsii pravovogo statusa lichnosti. [Universal Declaration of 1948: from catalogs of human rights to the unification of the legal status of individuals]. Pravovedeniye, №4, 34-35 [in Russian].

2. Buletsa, S. B. (2006). Pravo fizychnoyi osoby na zhyttya ta zdorov"ya (porivnyal'no-pravovyy aspekt). [The right of an individual to life and health (comparative legal aspect)]. Monohrafiya. Uzhhorod, Polihraftsentr „Lira”, [in Ukrainian].

3. Danilov, S. O. (2002). Ideya nevid"yemnykh prav lyudyny u Konstytutsiyi Ukrayiny. [The idea of inalienable human rights in the Constitution of Ukraine]. Derzhava i pravo, 18, .61-65 [in Ukrainian].

4. Zaytseva, A. M. (2008). Zhizn' cheloveka kak ob»yekt konstitutsionno pravovogo regulirovaniya. [Human life as an object of constitutional legal regulation]. (Extended abstract of Candidat's thesis). M. [in Russian].

5. Kal'chenko, N. V. (2004). Grazhdanskiye prava cheloveka: sovremennyye problemy teorii i praktiki. [Civil human rights: modern problems of theory and practice]. Monografiya. Volgograd, [in Russian].

6. Kal'chenko, N. V. (1995). Pravo cheloveka i grazhdanina na zhizn' $i$ yego garantii v RF. [The human and citizen's right to life and its guarantees in the Russian Federation]. (Candidat's thesis). Volgograd [in Russian].

7. Karako, P. S. (1998). Zhizn' [Life]. Noveyshiy filosofskiy slovar.' Sost. A.A. Gritsianov. Minsk: Izd. V.M. Skakun, [in Russian].

8. Kozhan, V. V. (2016). Osobysti prava ta svobody lyudyny: zahal'noteoretychne doslidzhennya. [Personal rights and human freedoms: general theoretical research]. (Candidat's thesis). L'viv, 2016, [in Ukrainian].

9. Kolodiy, A.M. \& Oliynyk, A. YU. (2008). Prava, svobody ta obov'yazky lyudyny i hromadyanyna v Ukrayini. [Rights, freedoms and responsibilities of man and citizen in Ukraine]. Pidruchnyk. K., Vseukrayins'ka asotsiatsiya vydavtsiv «Pravova yednist'», [in Ukrainian]

10. Krasavchikova, L. O. (1983). Lichnaya zhizn' grazhdan pod okhranoy zakona. [The personal life of citizens is protected by law]. M.: Yuridicheskaya literatura, $160 \mathrm{~s}$. [in Russian].

11. Kuz'menko, YA. P. (2014). Zahal'na kharakterystyka prava lyudyny na zhyttya. [General characteristics of the human right to life]. Naukovyy visnyk Uzhhorods'koho natsional'noho universytetu. Seriya PRAVO, 28, Tom 1 , 26-30 [in Ukrainian].

12. Kuz'menko, YA. P. (2015). Pravo lyudyny na zhyttya: istoryko-pravovi aspekty. [People's right to life: historical and legal aspects]. Yurydychnyy naukovyy elektronnyy zhurnal, 3, 25. Available from: http://www.lsej.org. ua/3_2015/6.pdf [in Ukrainian].

13. Kuz'menko, YA. P. (2017). Pravo na zhyttya yak pryrodne pravo lyudyny: teoretyko-pravovyy analiz. [The right to life as a natural human right: theoretical and legal analysis]. Naukovyy visnyk Uzhhorods'koho natsional'noho universytetu. Seriya «Pravo», 46, T.1, 15-18 [in Ukrainian].

14. Matuzov, N. I. (1998). Pravo na zhizn' v svete rossiyskikh i mezhdunarodnykh standartov. [The right to life in the light of Russian and international standards]. Pravovedeniye, 1, 198-203 [in Russian].

15. Oparim, A. Y. (1978). Zhizn'. [Life]. Bol'shaya meditsinskaya entsiklopediya. [Great medical encyclopedia]. GL. red. akad. B.V. Petrovskiy. T.8: Yevgenika-Zybleniye. M., Izd. «Sovetskaya zntsiklopediya», S.253-258. [in Russian].

16. Pro zakhyst prav lyudyny $i$ osnovopolozhnykh svobod. [On the protection of human rights and fundamental freedoms]. (1950): Konventsiya. Available from: https://zakon.rada.gov.ua/laws/show/995_004\#Text [in Ukrainian].

17. Pro sudovu praktyku $v$ spravakh pro zlochyny proty zhyttya ta zdorov'ya osoby. [On Judicial Practice in Cases of Crimes against the Life and Health of a Person]. (2003): postanova Plenumu Verkhovnoho Sudu No 2. Available from: https://zakon.rada.gov.ua/laws/show/ v0002700-03\#Text [in Ukrainian].

18. Punda 0. 0. (2004). Pravo na fizychnu nedotorkannist' u systemi osobystykh nemaynovykh prav fizychnoyi osoby. [The right to physical inviolability in the system of personal non-property rights of an individual]. Visnyk Verkhovnoho Sudu Ukrayiny, 7(47), 38-40 [in Ukrainian].

19. Rabinovych, P. M. \& Khavronyuk, M. I. (2004). Prava lyudyny $i$ hromadyanyna [Human and civil rights]. Navchal'nyy posibnyk. K. Atika, 464 s. [in Ukrainian].

20. Rohova, O.H. (2006). Pravo na zhyttya $v$ systemi prav lyudyny. [The right to life in the human rights system] (Extended abstract of Candidat's thesis). KH. [in Ukrainian].

21. Romanovs'kyy, H. B. (2006). Pravo na zhyzn': yurydycheskaya norma y doktryna [The right to life: legal norm and doctrine]. Universytet.s'ki naukovi zapysky, 2(18), 75-79. [in Russian]. 
22. Rubanova, N. A. (2006). Pravo lyudyny na zhyttya $v$ zakonodavstvi RF: ponyattya, zmist, pravove rehulyuvannya [The human right to life in the legislation of the Russian Federation: concept, content, legal regulation] (Extended abstract of Candidat's thesis). Rostov-na-Donu. [in Russian].

23. Selykhova, O. H. (2002). Konstytutsiyno-pravovi problemy zdiysnennya prava indyvidiv na svobodu ta osobystu nedotorkannist'. [Constitutional and legal problems of the exercise of the right of individuals to freedom and personal inviolability]. Extended abstract of Candidat's thesis). Yekaterynburh [in Russian].

24. Sloma, V. M. (2012). Pravo na zhyttya yak osobyste nemaynove pravo fizychnoyi osoby. [The right to life as a personal intangible right of an individual]. Yurydychnyy visnyk, 1(22), 77-81. Available from: http://www. law.nau.edu.ua/images/Nauka/Naukovij_jurnal/2012/ statji_n1_22_2012/Sloma_77.pdf [in Ukrainian].

25. Stefanchuk, R. O. (2004). Pravo na zhyttya yak osobyste nemaynove pravo fizychnoyi osoby [The right to life as a personal intangible right of an individual]. Yurydychna Ukrayina, №7, 44-49 [in Ukrainian].

26. Stefanchuk, R. O.(2003). Tsyvil'no-pravovi zasady zakriplennya, zdiysnennya ta okhorony prava na zhyttya yak osobystoho nemaynovoho prava fizychnykh osib. [Civil law principles of consolidation, exercise and protection of the right to life as a personal non-property right of individuals]. Metodolohiya pryvatnoho prava: Zb nauk. prats'. K. Yurinkom Inter [in Ukrainian].

27. Sudo, Z. H. (2001). Biolohichnyy status lyuds'koho embriona (dopovid' dlya medykiv). [Biological status of the human embryo (report for physicians)]. Rodyna $i$ byoétyka, 5, 131-139 [in Ukrainian].

28. Fedorova, A. L. (2009). Pravo na zhyttya yak nevi- d"yemne pryrodne pravo lyudyny. [The right to life as an inalienable natural human right].. Aktual'ni problemy mizhnarodnykh vidnosyn, 83, (Chastyna II), 43-49 [in Ukrainian].

29. Tsyvil'nyy kodeks Ukrayiny. [Civil Code of Ukraine]. (2003): Zakon Ukrayiny №435-IV. Available from: https://zakon.rada.gov.ua/laws/show/435-15\#Text [in Ukrainian].

30. Shevchenko, Yu. A. (2018). Mekhanizm zakhystu prava na zhyttya u svitli praktyky yevropeys'koho sudu z prav lyudyny u spravakh proty Ukrayiny. [Mechanism for the protection of the right to life in the light of the case law of the European Court of Human Rights in cases against Ukraine.]. Young Scientist, 3 (55), March, 301307/]/ [in Ukrainian].

31. 대한민국헌법 [시행 1988. 2. 25.] [헌법 제10호, 1987. 10. 29., 전부개정]. [The Constitution of the Republic of Korea [Enforcement on February 25, 1988] [Constitution No. 10, October 29, 1987, all amended]. Available from: https://www.law.go.kr/LsEflnfoP.do?tsiSeq=61603\# [in Korean].

32. 中村 美帆. Nakamura, Miho (2017) 日本国憲法第25 条「文化」概念の研究一文化権（cultural right）亡 の関連性. [Research on the concept of “culture" in Article 25 of the Japanese Constitution-Relationship with cultural rights].. Available from: http://www.l.u-tokyo. ac.jp/postgraduate/database/2017/6187.html [in Japanese].

33. 日本国憲法. [Constitution of Japan]. (1945). Available from: https://elaws.e-gov.go.jp/document?lawid=321CONSTITUTION [in Japanese].

34. 生活保護制度. [Life protection system]. Available from: https://www.gender.go.jp/policy/no_violence/e-vaw/ law/22.html [in Japanese].

UDC 342.72/.73

ЖИТТЯ ТА ПРАВО НА ЖИТТЯ ЯК ОСНОВНЕ КОНСТИТУЦІЙНЕ ПРАВО ГРОМАДЯНИНА Сібілла Булеца,

завідувач кафедри цивільного права та процесу

Ужгородського національного університету,

доктор юридичних наук, професор

https://orcid.org/0000-0001-9216-0033

Scopus ID:

https://www.scopus.com/authid/detail.uri?authorId $=57201856837$

ResearcherID: G-2664-2019

(https://publons.com/researcher/1766597/sibilla-buletsa/)

sibilla.buletsa@uzhnu.edu.ua 


\section{Резюме}

Мета цієї статті - вивчити поняття життя та конституційне право на життя, визначити іх сутність, взаємозвязок цих понять, розкрити їх особливості, а також досвід Європейського суду з прав людини щодо їх захисту.

В контексті розкриття предмета дослідження для досягнення мети наукового дослідження та забезпечення повноти, об'єктивності, надійності та переконливості результатів автор використав комплекс загальних та спеціальних методів, характерних для юридичної науки. Зокрема, за допомогою історичного методу було вивчено походження та довгий історичний шлях розвитку цих прав людини. За допомогою системно-структурного методу сформульовано загальну структуру дослідження, а діалектичного - проаналізовано положення законодавства та судової практики щодо особливостей права на життя. За допомогою порівняльно-правового методу було проаналізовано законодавство зарубіжних країн, що дало можливість використовувати їх позитивний досвід з точки зору захисту права на життя людини.

у цій статті розкриваються наукові підходи дослідників щодо визначення сутності життя, права на життя, смерті, виявлення їх особливостей та розмежування між ними. У статті проаналізовано способи захисту права на життя. Значна частина роботи присвячена аналізу правозастосовчої практики Європейського суду з прав людини як загалом, так і доцільності існування певних критеріїв обмеження права на життя.

На підставі дослідження зроблено висновок, що життя та право на життя $\epsilon$ подібними поняттями. Стверджується, що обмеження права на життя через пандемію можливі у разі підтвердження захворювання. У всіх інших випадках держава повинна забезпечити вільний доступ до тестування на коронавірус, у разі негативного тесту можливість вільно реалізувати право на життя. Відзначається, що значна кількість зарубіжних країн передбачає право на життя в конституціях, але є країни, де право на щастя чи фізичне благополуччя розвивається. Загальновідомо, що кожен має право на щастя, яке у кожного різне, тому створення механізму забезпечення та дотримання права на життя лежить на державі та людині.

Ключові слова: життя, право на життя, людина, Конституція, Європейський суд, захист. 